\title{
Nitrification Studies at Non-limiting Substrate Concentrations
}

\author{
By J. I. PROSSER AND T. R. G. GRAY \\ Hartley Botanical Laboratories, University of Liverpool, P.O. Box I47, \\ Liverpool L69 $3 B X$
}

(Received 10 February 1977; revised 6 May 1977)

Theoretical models of nitrification were tested using an experimental model consisting of a column of glass beads inoculated with nitrifying bacteria, through which was passed a constant flow of substrate at non-limiting concentration. Effluent was analysed for conversion products. Both zero-order and first-order rate constants for substrate conversion decreased by $\mathrm{I} \cdot 4 \%$ for each $\mathrm{I} \mathrm{ml} \mathrm{h}^{-1}$ decrease in flow rate presumably because of the development of oxygen limitation. Logistic growth kinetics descriked growth adequately and bacteria were distributed evenly throughout the column after establishment of steady states. Bacterial concentrations of $\mathrm{I} \cdot 4 \times 10^{9} \mathrm{ml}^{-1}$ and conversion rates of $5.62 \times \mathrm{IO}^{-9}$ p.p.m. N as $\mathrm{NO}_{2}^{-} \mathrm{h}^{-1}$ organism ${ }^{-1}$ were obtained for Nitrobacter and $6.47 \times 10^{6} \mathrm{ml}^{-1}$ and $3.75 \times 10^{-7}$ p.p.m. $\mathrm{N}$ as $\mathrm{NH}_{4}^{+} \mathrm{h}^{-1}$ organism ${ }^{-1}$ for Nitrosomonas. During periods of oxygen starvation a lag was observed following increases in flow rate producing undershoots in product concentrations before establishment of new steady states.

\section{INTRODUCTION}

The dynamics of nitrification have recently been studied by means of experimental and theoretical models. Macura \& Kunc (1965) passed ammonium ions continuously through a soil column and analysed the effluent for ammonium, nitrite and nitrate ions. Ardakani, Rehbock \& McLaren (1973) extended this system by having sample ports to observe behaviour at different depths within the column. Bazin \& Saunders (I973) replaced the soil with glass beads and provided an inorganic medium containing ammonium ions after inoculation of the beads with pure cultures of nitrifying bacteria. This provided a completely defined system in which all environmental factors such as temperature, particle size and initial inoculum size could be controlled and measured.

Several theoretical models have been derived describing nitrification in such systems (for review, see Bazin, Saunders \& Prosser, 1976). These consist of equations describing changes in ammonium, nitrite and nitrate concentrations during nitrification and, in some, changes in biomass. Conversion of ammonium to nitrite by Nitrosomonas and nitrite to nitrate by Nitrobacter follow either zero-order (Saunders \& Bazin, 1973a), first-order (McLaren, 197I; Cho, 1971; Saunders \& Bazin, 1973b) or intermediate order kinetics (Bazin \& Saunders, I973), and biomass is either assumed to be at a constant maximum or is described by Monod kinetics or by the logistic equation (Pielou, 1969).

The aim of our studies was to test these models using the experimental system of Bazin \& Saunders. Initially, inoculation of a strain of a single genus, either Nitrosomonas or Nitrobacter, and a substrate supply at high concentration were investigated. In this way the system was simplified as much as possible by eliminating interactions between the different strains and preventing growth limitation imposed by sub-optimal substrate concentration. It allowed ammonium and nitrite oxidation to be studied independently. A column inoculated 
with strains of both genera of nitrifiers was also investigated, allowing assessment of any interactions.

The above models consider a column of uniform cross-sectional area containing particulate material and uniformly distributed nitrifying bacteria through which is passed a constant flow of inorganic medium containing ammonium ions. Temperature and $\mathrm{pH}$ are assumed to be constant, contaminating organisms are assumed to be absent, and hydrodynamic dispersion, diffusion, ion exchange and assimilation of ammonium, nitrite and nitrate are assumed to be negligible [except in the model of Cho (I971) where dispersion and ion exchange are considered]. All predict the re-establishment of a steady state for effluent concentrations of ammonium, nitrite and nitrate ions after changes in flow rate, with a smooth approach to the new levels.

At high substrate concentrations the major distinction between the different models concerns the kinetics of substrate conversion. All models predict or assume establishment of a constant maximum population, independent of substrate concentration, and uniformly distributed throughout the column. However, some predict zero-order and some first-order rate kinetics. These can be distinguished by measuring steady state effluent concentrations of ammonium, nitrite and nitrate ions at different dilution rates. If conversion of ammonium to nitrite only is considered, the zero-order rate constant $\left(r_{0}\right)$ is given by: $r_{0}=D \bar{S}_{2}$, where $D$ is the dilution rate, and $S_{2}$ the nitrite concentration. (A bar represents a steady state value for the parameter.) The first-order rate constant $\left(r_{1}\right)$ is given by: $r_{1}=D \ln \left(S_{1} \mathbf{0} / \bar{S}_{1}\right)$, where $S_{1}{ }^{0}$ is the input ammonium concentration, and $S_{1}$ the effluent ammonium concentration. Thus, $r_{0}$ will be constant at different dilution rates only if zero-order rate kinetics apply and $r_{1}$ will be constant only if first-order rate kinetics apply.

\section{METHODS}

Maintenance of nitrifiers. Nitrifying bacteria were cultured in $250 \mathrm{ml}$ Erlenmeyer flasks on a Gallenkamp orbital incubator at $25^{\circ} \mathrm{C}$ in the media used by Skinner \& Walker (196I), for ammonium oxidizers, and van Droogenbroeck \& Laudelout (1967), for nitrite oxidizers. The presence of heterotrophic contaminants was detected by the presence of colonies after I4 days on plates of nutrient agar inoculated with suspect cultures. A strain of Nitrobacter agilis was provided by Dr N. Walker, Rothamsted Experimental Station, and the Nitrosomonas strain was isolated from china clay sand waste using the enrichment and dilution method of Soriano \& Walker (1968).

Kinetic studies. Kinetic studies were carried out in a column similar to that of Bazin \& Saunders (1973). This consisted of a glass tube of $15 \mathrm{~mm}$ internal diameter surrounded by a water jacket and sealed at the base with a sintered glass plate. It was filled to a height of approximately $300 \mathrm{~mm}$ with glass beads (diam. 0.06 to $0.10 \mathrm{~mm}$ ). For investigation of ammonium oxidation, marble chips were also added to neutralize any acid formed. Medium entered the column via a hypodermic needle (Luer no. $20 \mathrm{G} \times 2$ in) passed through a silicone rubber bung. Silicone rubber tubing was used throughout as nitrifiers are sensitive to carbon disulphide and other substances released from ordinary red rubber (Powlson \& Jenkinson, 1971).

The medium (Smith \& Hoare, 1968), containing either $\left(\mathrm{NH}_{4}\right)_{2} \mathrm{SO}_{4}$ or $\mathrm{NaNO}_{2}$, was added continuously using a LKB I 200 Varioperpex peristaltic pump. Water at $25^{\circ} \mathrm{C}$ was circulated through the water jacket and the column was surrounded by aluminium foil as nitrifiers are photosensitive (Hooper \& Terry, 1974). The dry weight of the column plus beads was determined and the whole system was autoclaved at O.I MPa for I5 to 20 min. Effluent from the base of the column was collected in test-tubes in a fraction collector at intervals of between 10 and $90 \mathrm{~min}$. If the effluent contained bacteria, $\mathrm{O} \cdot \mathrm{I} \mathrm{mg}$ thiomersal was added to each test-tube.

The column was inoculated by addition of suspensions subcultured at least twice in the medium of Smith \& Hoare (1968) initially containing ammonium or nitrite at the concentrations supplied to the column. Effluent samples were analysed for ammonium, nitrite and nitrate ions using a Technicon Auto-analyser II (Technicon Instruments Co., Basingstoke, Hampshire). Establishment of a steady state was detected using a test for dependence of nitrite and nitrate concentration on time (Green, 1970). The flow rate was then changed abruptly to a new constant value.

At the end of each experiment the column was weighed and the void volume was determined by subtraction. Dilution rate was calculated by dividing the flow rate by the void volume. For bacterial counts, the column was marked at equal intervals and known weights of beads from each section were placed in $10 \mathrm{ml}$ 


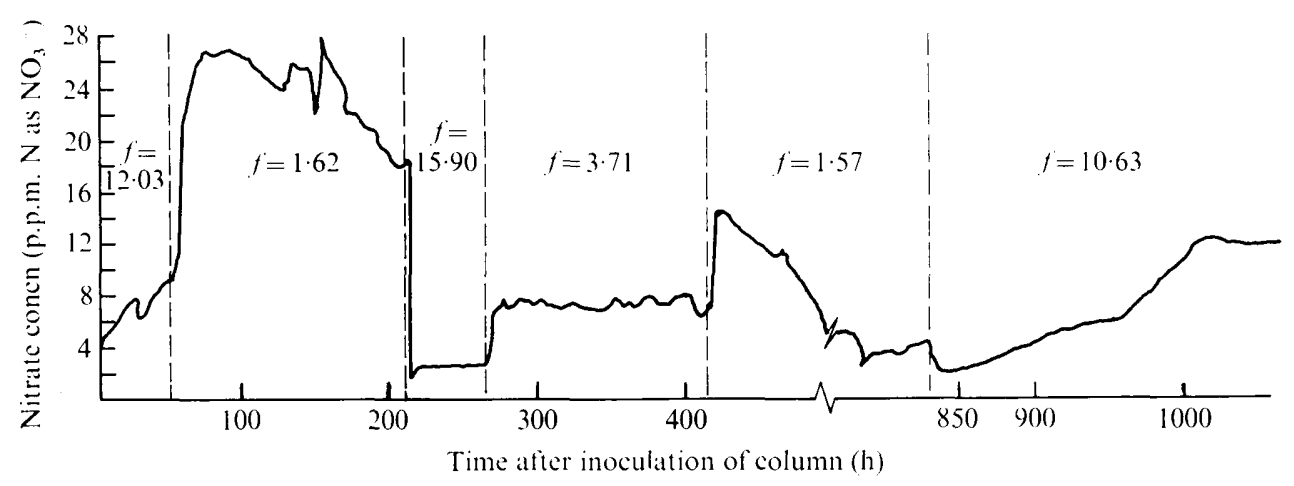

Fig. I. Changes in nitrate concentration with time for a column inoculated with Nitrobacter only. Line fitted through I 138 points. Samples were taken at intervals of $60 \mathrm{~min}$ from o to $214 \mathrm{~h}$, Io min from $2 \mathrm{I} 4$ to $278 \mathrm{~h}, 30 \mathrm{~min}$ from 278 to $400 \mathrm{~h}$ and $60 \mathrm{~min}$ from 400 to $1070 \mathrm{~h}$. Flow rate $(f)$ in $\mathrm{ml} \mathrm{h}^{-1}$.

of the appropriate medium. No precautions against aerial contamination were necessary. Each suspension was shaken and a series of Io-fold dilutions were made in the media used for maintaining cultures without ammonium or nitrite. Five $\mathrm{I} \mathrm{ml}$ samples were removed from each dilution, placed in test-tubes containing $6 \mathrm{ml}$ of complete medium and incubated for 3 weeks at $25{ }^{\circ} \mathrm{C}$ when the most probable number (MPN) of bacteria was determined (Meynell \& Meynell, 1970).

\section{RESULTS AND DISCUSSION}

\section{Studies with Nitrobacter}

Changes in nitrate concentration in a column inoculated with Nitrobacter only and supplied with 50 p.p.m. $\mathrm{N}$ as $\mathrm{NO}_{2}{ }^{-}$at different flow rates are shown in Fig. I. Decreasing the flow rate to $\mathrm{I} \cdot 62$ and $\mathrm{I} .57 \mathrm{ml} \mathrm{h}^{-1}$ at 50 and $4 \mathrm{IO} \mathrm{h}$, respectively, increased the nitrate concentration to initially steady values which subsequently decreased, presumably due to consumption of oxygen faster than it was supplied in the medium. At faster flow rates there was less time for oxidation, oxygen was not exhausted and steady states were established. After $750 \mathrm{~h}$ the inflowing medium was saturated with air by continuous bubbling of sterile air, and the nitrate concentration increased to give a steady state at ro $40 \mathrm{~h}$. Steady state nitrate concentration was I I 24 p.p.m. $\mathrm{N}_{\text {as }} \mathrm{NO}_{3}{ }^{-}$giving values of $r_{0}=7.87$ p.p.m. $\mathrm{h}^{-1}$ and $r_{1}=0.178 \mathrm{~h}^{-1}$. At this time a constant maximum population was present limited by either available space or oxygen concentration in the inflowing medium which was then constant.

The most probable numbers of bacteria in the effluent, in liquid blown out of the column and attached to beads at different depths in the column were determined (Table I). As too small a dilution range was used a minimum value only is available for numbers in the effluent, but liquid blown out of the column by application of compressed air to the top gave a count of $\mathrm{I} \cdot 3 \times 10^{6}$ bacteria $\mathrm{ml}^{-1}$. This represents the number of bacteria in free suspension within the column and is probably similar to the real number in the effluent.

There is no evidence from these results for a gradient of biomass down the column. The predictions of the models describing growth by the logistic equations are therefore not disproved. Ardakani et al. (1973) determined numbers of Nitrobacter at different depths in a sand-soil column supplied with 100 p.p.m. $\mathrm{N}$ as $\mathrm{NO}_{2}{ }^{-}$and found a reduction in numbers near the base of the column where all the nitrite had been utilized. However, in the above experiments the length of column and flow rate used were such that conversion was never complete within the column and so a reduction in numbers because of nutrient exhaustion would not have been expected. The mean most probable number of bacteria was $1 \cdot 4 \times 10^{9}$ $\mathrm{ml}^{-1}$ (S.E.M. $3.3 \times 10^{8}$ ) and the zero-order rate constant was 7.87 p.p.m. ${ }^{-1}$. This corresponds 
Table I. Estimated most probable numbers (MPN) of Nitrobacter in effluent, in blown-out liquid and on glass beads at different depths in the column following establishment of a steady state

The steady state was established at a flow rate of $10.63 \mathrm{ml} \mathrm{h}^{-1}$ giving a nitrate concentration of I I. 24 p.p.m. $\mathrm{N}$ as $\mathrm{NO}_{3}{ }^{-}$.

\begin{tabular}{|c|c|c|c|c|}
\hline & $\begin{array}{c}\text { MPN } \\
\text { (bacteria } \mathrm{ml}^{-1} \text { ) }\end{array}$ & $\begin{array}{c}\log _{10} \mathrm{MPN} \\
\left.\text { (bacteria ml } \mathrm{ml}^{-1}\right)\end{array}$ & 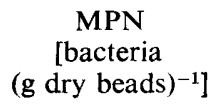 & $\begin{array}{r}\log _{10} \mathrm{MPN} \\
\text { [bacteria } \\
\text { (g dry beads) }\end{array}$ \\
\hline Effluent & $>2.4 \times 10^{5}$ & $>5 \cdot 38$ & & \\
\hline Liquid blown out & $1 \cdot 3 \times 10^{6}$ & $6 \cdot \mathrm{II}$ & & \\
\hline \multicolumn{5}{|l|}{$\begin{array}{l}\text { Column depth } \\
(\mathrm{mm})\end{array}$} \\
\hline $0-25$ & $2.6 \times 10^{8}$ & $8 \cdot 41$ & $3.46 \times 10^{6}$ & $6 \cdot 54$ \\
\hline $25-50$ & $5.86 \times 10^{8}$ & $8 \cdot 77$ & $7.8 \times 10^{6}$ & $6 \cdot 89$ \\
\hline $50-75$ & $3.8 \times 10^{8}$ & $8 \cdot 58$ & $5.06 \times 10^{6}$ & $6 \cdot 70$ \\
\hline $75-100$ & $>2.6 \times 10^{9}$ & $>9 \cdot 42$ & $>3.46 \times 10^{7}$ & $>7 \cdot 54$ \\
\hline $100-125$ & $8.57 \times 10^{7}$ & $7 \cdot 93$ & $\mathrm{I} \cdot \mathrm{I} 4 \times 10^{6}$ & 6.06 \\
\hline $125-150$ & $>2.6 \times 10^{9}$ & $>9.42$ & $>3.46 \times 10^{7}$ & $>7 \cdot 54$ \\
\hline $150-175$ & $3.58 \times 10^{7}$ & $7 \cdot 55$ & $476 \times 10^{5}$ & 5.68 \\
\hline $175-200$ & $1 \cdot 19 \times 10^{7}$ & 7.08 & $\mathrm{I} \cdot 58 \times 10^{5}$ & $5 \cdot 20$ \\
\hline $200-225$ & $>2.6 \times 10^{9}$ & $>9.42$ & $>3.46 \times 10^{7}$ & $>7 \cdot 54$ \\
\hline $225-250$ & $>2.6 \times 10^{9}$ & $>9 \cdot 42$ & $>3.46 \times 10^{7}$ & $>7 \cdot 54$ \\
\hline $250-275$ & $8.57 \times 10^{7}$ & $7 \cdot 93$ & $1 \cdot 14 \times 10^{6}$ & $6 \cdot 06$ \\
\hline $275-300$ & $>2.6 \times 10^{9}$ & $>9 \cdot 42$ & $>3.46 \times 10^{7}$ & $>7.54$ \\
\hline $300-325$ & $>2.6 \times 10^{9}$ & $>9 \cdot 42$ & $>3.46 \times 10^{7}$ & $>7.54$ \\
\hline $325-350$ & $>2.6 \times 10^{9}$ & $>9 \cdot 42$ & $>3.46 \times 10^{7}$ & $>7 \cdot 54$ \\
\hline
\end{tabular}

to a conversion rate per organism of $5.62 \times \mathrm{IO}^{-9}$ p.p.m. $\mathrm{N}$ as $\mathrm{NO}_{2}{ }^{-\mathrm{h}^{-1}}$ organism $^{-1}$, although this is probably an overestimate as minimum numbers only were available for some samples.

Two effects not predicted by the models were observed. The first was the presence and activity of bacteria in free suspension and in the effluent. This necessitated addition of thiomersal to test-tubes to prevent conversion of nitrite before analysis of the effluent. The numbers in liquid blown out from the column, however, were two orders of magnitude lower than the mean most probable number of organisms attached to the beads and their effect within the column will have been insignificant.

The second effect was the occurrence of a short undershoot (of about $4 \mathrm{~h}$ ) following the increase in flow rate at $2 \mathrm{I} 4 \mathrm{~h}$. The initial drop in nitrate concentration is due solely to change in flow and should have ended after the time for passage of liquid through the column. The subsequent rise to a new steady state level was not predicted by any of the models and may have been caused by the occurrence of limiting oxygen concentrations. Thus, at a flow rate of $\mathrm{r} .62 \mathrm{ml} \mathrm{h}^{-1}$ oxygen would have been exhausted or at very low concentration near the base of the column due to utilization in the top portion and so bacteria, although present in favourable conditions of $\mathrm{pH}$ and temperature, were inactive. At increased flow rates oxygen was not used up completely at the same depth, and would have become available to bacteria lower down. There could have been a short lag before these bacteria regained full activity (for synthesis or activation of the nitrite-oxidizing enzyme), after which nitrate concentration would have risen to its new level.

\section{Studies with Nitrosomonas}

Changes in nitrite concentration in a column inoculated with Nitrosomonas only and supplied with 106 p.p.m. $\mathrm{N}_{\text {as }} \mathrm{NH}_{4}{ }^{+}$at different flow rates are shown in Fig. 2. Steady state nitrite concentrations and the corresponding values of $r_{0}$ and $r_{1}$ at four flow rates are given in Table 2. Steady states were not obtained before $2880 \mathrm{~h}$ due to photo-inactivation of Nitrosomonas as a result of incomplete covering of the column. At the final three flow rates 


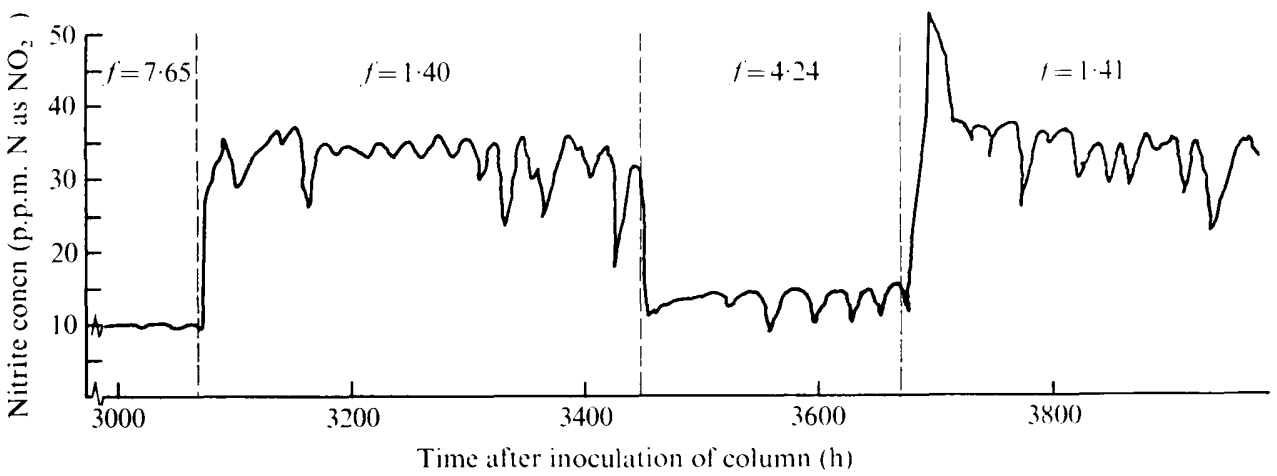

Fig. 2. Changes in nitrite concentration with time for a column inoculated with Nitrosomonas only. Line fitted through 684 points. Samples were taken at intervals of $90 \mathrm{~min}$ from 3000 to $3480 \mathrm{~h}$, $60 \mathrm{~min}$ from 3480 to $3504 \mathrm{~h}$ and $90 \mathrm{~min}$ from 3504 to $3980 \mathrm{~h}$. Flow rate $(f)$ in $\mathrm{ml} \mathrm{h}^{-1}$.

Table_2. Steady state nitrite concentrations and zero- and first-order rate constants for a column inoculated with Nitrosomonas

$\begin{array}{ccccc}\begin{array}{c}\text { Flow rate } \\ \left(\mathrm{ml} \mathrm{h}^{-1}\right)\end{array} & \begin{array}{c}\text { Dilution rate } \\ \left(\mathrm{h}^{-1}\right)\end{array} & \begin{array}{c}\text { Steady state } \\ \mathrm{NO}^{-} \text {concn } \\ \left(\text { p.p.m. Nas NO} \mathbf{2}^{-}\right)\end{array} & \begin{array}{c}r_{0} \\ \left(\text { p.p.m. } \mathrm{h}^{-1}\right)\end{array} & \begin{array}{c}r_{1} \\ \left(\mathrm{~h}^{-1}\right)\end{array} \\ \mathrm{I} \cdot 40 & 0.067 & 35.0 & 2.35 & 0.0269 \\ \mathrm{I} \cdot 4 \mathrm{I} & 0.068 & 35.5 & 2.4 \mathrm{I} & 0.0277 \\ 4.24 & 0.204 & 14.5 & 2.96 & 0.0300 \\ 7.65 & 0.367 & 9.92 & 3.64 & 0.036 \mathrm{I}\end{array}$

Table 3. Estimated most probable numbers (MPN) of Nitrosomonas in effluent and on glass beads + chips at different depths in the column following establishment of a steady state

The steady state was established at a flow rate of $\mathrm{I} \cdot 41 \mathrm{ml} \mathrm{h}{ }^{-1}$ giving a nitrite concentration of $35 \cdot 5$ p.p.m. $\mathrm{N}$ as $\mathrm{NO}_{2}^{-}$.

MPN $\quad \log _{10}$ MPN

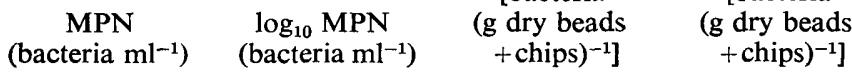

Effluent

$2 \cdot 2$

$0 \cdot 34$

Column depth $(\mathrm{mm})$

$0-30$
$40-60$
$70-90$
$100-120$
$130-150$
$160-180$
$190-210$
$220-240$
$250-270$
$280-300$

$7 \cdot 70$
$6 \cdot 64$
$6 \cdot 28$
$5 \cdot 51$
$5 \cdot 75$
$5 \cdot 92$
$6 \cdot 51$
$5 \cdot 33$
$5 \cdot 91$
$6 \cdot 31$

$I \cdot 82 \times 10^{6}$
$2.31 \times 10^{5}$
$I \cdot 40 \times 10^{5}$
$2 \cdot 15 \times 10^{4}$
$2 \cdot 39 \times 10^{4}$
$4.45 \times 10^{4}$
$I \cdot 79 \times 10^{5}$
$1 \cdot 15 \times 10^{4}$
$6.43 \times 10^{4}$
$9.08 \times 10^{4}$ $6 \cdot 26$ $5 \cdot 36$ $5 \cdot 15$ $4 \cdot 33$ $4 \cdot 38$ 4.65 5.25 4.06 4.81 $4 \cdot 96$

nitrite concentrations showed variation in daily cycles which cannot be satisfactorily explained and the steady state values were estimated by eye as the maxima of these cycles. Values of $r_{0}$ and $r_{1}$ should remain constant at different dilution rates if reaction kinetics are zero or first order respectively. In fact both $r_{0}$ and $r_{1}$ increased with increase in dilution rate.

After $3980 \mathrm{~h}$ the column was dismantled and numbers of Nitrosomonas were estimated in the effluent and at different parts of the column (Table 3). Less bacteria were washed out than in the previous experiment with Nitrobacter and activity in the samples before analysis 
Table 4. Steady state nitrate concentrations and zero- and first-order rate constants for a column inoculated with Nitrobacter and Nitrosomonas

\begin{tabular}{|c|c|c|c|c|}
\hline $\begin{array}{c}\text { Flow rate } \\
\left(\mathrm{ml} \mathrm{h}^{-1}\right)\end{array}$ & $\begin{array}{c}\text { Dilution rate } \\
\qquad\left(\mathrm{h}^{-1}\right)\end{array}$ & $\begin{array}{c}\text { Steady state } \\
\mathrm{NO}_{3}^{-} \text {concn } \\
\text { (p.p.m. } \mathrm{N} \text { as } \mathrm{NO}_{3}{ }^{-} \text {) }\end{array}$ & $\begin{array}{c}r_{0} \\
\text { (p.p.m. } \mathrm{h}^{-1} \text { ) }\end{array}$ & $\begin{array}{c}r_{1} \\
\left(\mathrm{~h}^{-1}\right)\end{array}$ \\
\hline$I \cdot 56$ & $0.08 \mathrm{I}$ & I5.48 & I $\cdot 254$ & 0.0128 \\
\hline I.92 & 0.100 & I 2.89 & I $\cdot 289$ & 0.0130 \\
\hline 3.65 & 0.190 & $7 \cdot 30$ & $\mathrm{I} \cdot 387$ & 0.0136 \\
\hline
\end{tabular}

was negligible. Again there was no evidence of a biomass gradient and numbers in the column were two to three orders of magnitude lower than for Nitrobacter. Ardakani, Rehbock \& McLaren (I974) determined numbers of Nitrosomonas in a sand-soil column supplied with ammonium and found a reduction in numbers near the base of the column where ammonium had been completely utilized. Such a reduction would not be expected here because conversion was never complete within the column.

This, and the previous experiment, confirmed that logistic growth kinetics provide sufficient description at high ammonium concentration, and for practical purposes the assumption of a constant population may be valid. This may not, however, be a maximum population in terms of available space. If a bead diameter of $0.08 \mathrm{~mm}$ is assumed, then results from columns inoculated with Nitrobacter and Nitrosomonas give $7 \cdot 20 \times 10^{6}$ and $\mathrm{I} \cdot 75 \times 10^{3}$ bacteria $\mathrm{cm}^{-2}$, respectively. If each bacterium is assumed to occupy $\mathrm{IO}^{-8} \mathrm{~cm}^{2}$ then these values correspond to intercellular distances of $13 \cdot \mathrm{I}$ and $293 \mu \mathrm{m}$, which are large in relation to the size of the bacteria. Whether bacteria were evenly distributed or occurred in clumps or colonies could not be determined. If they were evenly distributed, however, these values suggest either that the maximum population was not attained, and that limitation was caused by some other factor such as washout, or that there was a high degree of intercellular interference particularly with Nitrosomonas.

\section{Studies with Nitrobacter and Nitrosomonas}

In a column inoculated with both Nitrobacter and Nitrosomonas and supplied with I06 p.p.m. $\mathrm{N}$ as $\mathrm{NH}_{4}{ }^{+}$, the nitrite concentration was very low at all three flow rates used $\left(\mathrm{I} \cdot 56,3.65\right.$ and $\mathrm{I} \cdot 92 \mathrm{ml} \mathrm{h} \mathrm{h}^{-1}$ in comparison with nitrate concentration and never rose above 0.62 p.p.m. with most values between 0.25 and 0.40 p.p.m. The only significant variation followed a reduction in flow rate to $\mathrm{r} \cdot 92 \mathrm{ml} \mathrm{h}^{-1}$ at $760 \mathrm{~h}$, when nitrite concentration increased to 0.62 p.p.m. and then fell to the previous level of 0.35 p.p.m.

Steady state nitrate levels were obtained at three different flow rates and the corresponding values for $r_{0}$ and $r_{1}$ are given in Table 4 . As in the previous experiment both $r_{0}$ and $r_{1}$ decreased with decrease in dilution rate. However, the values here were lower, suggesting establishment of a smaller population of Nitrosomonas because of competition with Nitrobacter.

Bazin \& Saunders (1973) inoculated a glass bead system with both nitrifiers and supplied Io6 p.p.m. $\mathrm{N}_{\text {as }} \mathrm{NH}_{4}{ }^{+}$but obtained much higher levels of nitrite than were found here. This could be due to use of different nitrifier strains or to the partial aeration of their columns. The latter would increase the oxygen concentration which could increase nitrite oxidation relative to ammonium oxidation. It may also explain our failure to observe the overshoots in nitrite and nitrate concentrations following decrease in flow rate that were observed by these workers. Ardakani et al. (1974) found negligible amounts of nitrite but this was probably due to previous enrichment of the soil with nitrite allowing development of a maximum Nitrobacter population before addition of ammonium. Very low nitrite concentrations are found in soils which are actively nitrifying. In the column, Nitrobacter attained populations about roo times greater than Nitrosomonas. Thus, although the rate of oxidation per organism for Nitrobacter is less than that for Nitrosomonas, their larger numbers result in conversion of nitrite as soon as it is formed from ammonium. 
The most significant difference between predicted and experimental results is the deviation from both first- and zero-order kinetics, as both $r_{0}$ and $r_{1}$ decreased with reduction in dilution rate. One explanation for this behaviour is oxygen limitation or exhaustion within the column. At the lower flow rates more substrate is oxidized than at faster rates where there is less time for conversion. Thus, overall oxygen concentration may be less at lower flow rates and while such levels would not stop conversion in any part of the column, as in the first experiment, it may be low enough to limit it. To overcome this discrepancy, oxygen concentration should be considered in the equations. Experimentally, oxygen concentration could be increased to non-limiting levels by using unsaturated flow conditions, with sterile air pumped through the column, but this would increase model complexity as the heterogeneity introduced is more difficult to describe correctly.

An alternative is to make a factor other than oxygen concentration limiting. Thus, if ammonium is supplied at low concentrations this will limit growth and activity and oxygen concentration need not be considered. This approach also allows study of growth kinetics at substrate concentrations nearer those found in soil and has been employed by Prosser \& Gray (1977).

J. I. Prosser wishes to acknowledge receipt of a N.E.R.C. Research Studentship.

\section{REFERENCES}

ARdakani, M. S., Rehbock, J.T. \& MCLaren, A. D. (1973). Oxidation of nitrite to nitrate in a soil column. Proceedings of the Soil Science Society of America 37, 53-56.

ARdaKani, M.S., Rehbock, J.T. \& McLaren, A. D. (1974). Oxidation of ammonium to nitrate in a soil column. Proceedings of the Soil Science Society of America 38, 69-99.

Bazin, M. J. \& Saunders, P. T. (I973). Dynamics of nitrification in a continuous flow system. Soil Biclogy and Biochemistry 5, 53 I-543.

Bazin, M. J., Saunders, P. T. \& Prosser, J. I. (1976). Models of microbial interactions in the soil. CRC Critical Reviews in Microbiology 4, 463-498.

CHо, C. M. (1971). Convective transport of ammonium with nitrification in soil. Canadian Journal of Soil Science 51, 339-350.

vaN DROOGENBRoeck, R. \& LAUdelout, H. (I967). Phosphate requirements of the nitrifying bacteria. Antonie van Leeuwenhoek 33, 287-296.

GreEn, J. R. (1970). A test for dependence. Biometrika 57, 205-206.

Hooper, A. B. \& Terry, K. R. (1974). Photoinactivation of ammonia oxidation in Nitrosomonas. Journal of Bacteriology II9, 899-906.

MCLAREN, A. D. (197I). Kinetics of nitrification in soil: growth of the nitrifiers. Proceedings of the Soil Science Society of America 35, 91-95.

MacurA, J. \& KunC, F. (1965). Continuous flow method in soil microbiology. V. Nitrification. Folia Microbiologica 1o, I25-I35.
Meynell, G. G. \& Meynell, E. (1970). Theory and Practice in Experimental Biology. London: Cambridge University Press.

Pielou, E. C. (1969). An Introduction to Mathematical Ecology. New York: Wiley Interscience.

PowLson, D. S. \& JeNkinson, D. S. (I97I). Inhibition of nitrification in soil by carbon disulphide from rubber bungs. Soil Biology and Biochemistry 3, 267-269.

Prosser, J. I. \& Gray, T. R. G. (1977). Use of finite difference method to study a model system of nitrification at low substrate concentrations. Journal of General Microbiology 102, 1 19-128.

SAunders, P. T. \& BazIN, M. J. (1973a). Attachment of micro-organisms in a packed column: metabolite diffusion through the microbial film as a limiting factor. Journal of Applied Chemistry and Biotechnology 23, 847-853.

SAunders, P. T. \& BAZIN, M. J. (1973b). Nonsteady state studies of nitrification in soil: theoretical considerations. Soil Biology and Biochemistry 5, 545-557.

SKINNER, F. A. \& WALKER, N. (1961). Growth of Nitrosomonas europaea in batch and continuous culture. Archiv für Mikrobiologie 38, 339-349.

SMITH, A. J. \& HOARE, D. S. (I968). Acetate assimilation by Nitrobacter agilis in relation to its 'obligate autotrophy'. Journal of Bacteriology 95, 844-855.

SORIANO, S. \& WALKER, N. (I968). Isolation of ammonia-oxidising autotrophic bacteria. Journal of Applied Bacteriology 31, 493-497. 